\title{
Investigation of immobilization and hydrolytic properties of pectinase onto chitosan-PVA copolymer
}

\author{
Inderjeet Kaur $^{1 *}$, Reena Gupta ${ }^{2}$, Anupam Lakhanpal ${ }^{2}$ And Atul Kumar ${ }^{1}$ \\ ${ }^{I}$ Department of Chemistry, H.P. University, Shimla, Himachal Pradesh, India 171005 \\ 2 Department of Bio Technology, H.P. University, Shimla, Himachal Pradesh, India 171005 \\ *Corresponding authorE-mail: ij_kaur@hotmail.com
}

\begin{abstract}
Copolymer based on natural polysaccharide, Chitosan, Chs and synthetic polymer, poly vinyl alcohol, PVA was synthesized using ammonium persulfate as radical initiator and sodium bicarbonate as foaming agent. Reaction conditions were optimized based on swelling percentage of copolymer. The copolymer, (Chs-co-PVA), was characterized by FTIR, SEM and XRD methods and was used as a support for immobilizing pectinase. The immobilized enzyme was found to be more stable than free enzyme and has a good binding efficiency $(88.29 \%)$ with the copolymer. The effect of temperature, $\mathrm{pH}$ and metal ions on the activity of the bound enzyme towards hydrolysis of poly- $\alpha-(1-4)-D-$ galacturonic acid (PGA) was investigated.
\end{abstract}

Keywords: Chitosan-PVA Copolymer, Pectinase, Immobilization, Hydrolysis, Polygalacturonic Acid.

\section{Introduction}

Recently, copolymers from natural and synthetic polymers, because of their inherent properties, are investigated extensively as they can be used as biomedical and biodegradable materials (Cascone et al. 2001). In the present study, a copolymer from natural polysaccharide, Chitosan and synthetic polymer, polyvinyl alcohol (PVA) has been synthesized. Chitosan, a copolymer of glucosamine and $\mathrm{N}$-acetyglucosamine units, is one of the most abundant natural amino polysaccharide. Special properties like high solubility, biodegradable, biocompatible, non-toxic, mucoadhesive and anti-bacterial nature of Chitosan makes it useful in different fields like industrial, pharmaceutical and biotechnological (Majeti and Kumar, 2000) such as biomaterial production, enzyme immobilization, drug delivery, wound dressing, dental applications etc (Lei, 2003; Oh et al., 2008; Prabaharan, 2005).

PVA, on the other hand, is a water-soluble polyhydroxy synthetic polymer, possessing unique properties of high degree of swelling in water, desirable mechanical properties and low toxicity and as such plays a significant role in biomaterial engineering such as artificial cartilage, drug delivery systems, microorganism enwrapping, cell micro-capsulation, anti-thrombin materials, and biomedical sponges (Francois et al., 2007; Coluccio et al., 2006; Bajpai and Manish, 2006). Therefore, combining the intrinsic properties of the natural polymer, Chitosan, and synthetic polymer, PVA, in the form of a blend or a copolymer, would bring forward a material with enhanced applications. Chitosan blended with PVA has been reported to have good mechanical and chemical properties and have been extensively used for water treatment, controlled drug-release and is beneficiary for dye adsorption (Ngah et al., 2004; Kumar et al. 2009; Wang et al., 2005; Liang et al., 2009). The copolymer from Chitosan and PVA, Chitosan-co-PVA, prepared by chemical method has been used as a support for enzyme immobilization. Among various known enzymes, pectinases are heterogeneous pectinolytic group of enzymes that catalyze the hydrolysis of pectin substances responsible for the turbidity and undesirable cloudiness in fruits juices.

Chemical immobilization of pectinase on $\mathrm{Fe}_{3} \mathrm{O}_{4} / \mathrm{SiO}_{2}-\mathrm{g}$ poly(PSStNa)-cl-Chitosan $\quad\left(\mathrm{Fe}_{3} \mathrm{O}_{4} / \mathrm{SiO}_{2} / \quad\right.$ poly(sodium4styrenesulfonate)/Chitosan) nano-composite microspheres was studied by Lei et al. (2011) The immobilized enzyme showed improved storage stability as well as enhanced performance at higher temperatures and over a wider $\mathrm{pH}$ range. Szaniawski and Spencer (1997) examined the effect of immobilized pectinase on the microfiltration of dilute pectin solutions by macroporous titanium membranes and immobilized enzyme was found to be very effective for the degradation of the pectin solution. The macroporous polyacrylamide (PAAm) microspheres with large surface area were used to covalently immobilize pectinase onto them (Lei and Jiang, 2011). The immobilized pectinase displayed improved thermal and storage stability and also exhibited better reusability than pectinase entrapped in alginate reported by Roy et al.(2003)

From the foregoing discussion, it is thus observed there is a meager data on supports such as the copolymer of two polymeric backbones offering a combination of different functional groups to trap the enzymes. In view of the above, it was therefore, thought worthwhile to prepare a copolymer based on Chitosan and PVA and used it as a support for the immobilization of pectinase. The prepared copolymer was characterized and the hydrolytic properties of the immobilized pectinase were evaluated with respect to the temperature, $\mathrm{pH}$ and metal ions.

\section{Experimental}

\subsection{Materials and method}


Chitosan (Himedia, Mumbai, India), PVA (Qualikems Fine Chem. Pvt. Ltd., Vadodara, India), sodium bicarbonate $\left(\mathrm{NaHCO}_{3}\right)$ (S.D. Fine, Mumbai), a foaming agent and ammonium persulfate (APS) (S.D. Fine, Mumbai), a free radical initiator, were used as received. Distilled water was used throughout the study as the reaction medium.

Tri sodium citrate buffer (Himedia, Mumbai, India), polygalacturonic acid (PGA) (Sigma-Aldrich, Steinheim, Germany) were used as received. Metal ions (Himedia, Mumbai, India and S.D. Fine, Mumbai), Pectinase (Department of Biotechnology, H.P.University, Shimla, H.P., India), glutaraldehyde (Lancaster Synthesis, Eastgate White Lund, Morecambe, England), and bovine serum albumin (Sisco Research Laboratory, Mumbai, India) were of analytical grade and were used as received.

\subsection{Synthesis of chitosan-PVA copolymer}

The copolymer, Chitosan-co-PVA, was prepared by chemical method. PVA $(0.500 \mathrm{~g})$ was dissolved in $3 \mathrm{~mL}$ of distilled water at room temperature and to it was added Chitosan $(0.500 \mathrm{~g})$ and dissolved. The mixture was stirred to prepare a thick dispersion and to it was added the initiator, APS (10.96 $\times 10^{-2}$ to $25.58 \times 10^{-2}$ $\mathrm{mol} / \mathrm{L}$ ) and the resulting dispersion was again stirred for 3-4 min. In the meantime, $\mathrm{NaHCO}_{3}\left(9.92 \times 10^{-2}-13.88 \times 10^{-2} \mathrm{~mol} / \mathrm{L}\right)$ was also added during stirring. Thick dispersion so obtained was heated for $4 \mathrm{~h}$ at $70^{\circ} \mathrm{C}$. After the stipulated time, the product was washed thoroughly with water and dried.

\subsection{Enzyme assay and protein estimation}

Pectinase assay was done by standard colorimetric method using polygalacturonic acid as substrate. The reducing sugars released were measured by arsenomolybdate method of Nelson (1944) and Somogyi(1952). Protein estimation was carried out by the method of Lowry et al (1951).

\subsection{Immobilization of pectinase onto chitosan-co-PVA copolymer}

Pectinase was immobilized onto the Chitosan-co-PVA copolymer support through physical adsorption. About $5 \mathrm{~g}$ of powdered Chitosan-co-PVA copolymer was incubated with $10 \mathrm{ml}$ tri-sodium citrate buffer $0.05 \mathrm{M}$ of $\mathrm{pH} 5.0$ for $1 \mathrm{~h}$ at $37^{\circ} \mathrm{C}$ in a water bath. 10 $\mathrm{ml}$ of purified pectinase $(15.98 \mathrm{U} / \mathrm{ml}$, protein content $0.102 \mathrm{mg}$ and specific activity $156.66 \mathrm{U} / \mathrm{mg}$ ) was added to matrix and incubated for $1 \mathrm{~h}$ at $37^{\circ} \mathrm{C}$. The matrix was then given 3-4 washings with tri-sodium citrate buffer $(0.05 \mathrm{M}, \mathrm{pH} 5.0)$ to get rid of unbound enzyme. The matrix-bound pectinase was then cross-linked using glutaraldehyde $(1 \%, \mathrm{v} / \mathrm{v})$ for $1 \mathrm{~h}$ at $37^{\circ} \mathrm{C}$ in a water-bath. The matrix-bound biocatalyst was further given 3 washings with tri-sodium citrate buffer $(0.05 \mathrm{M}, \mathrm{pH} 5.0)$ to get rid of traces of activating agent. Enzyme activity was determined using $20 \mathrm{mg}$ of immobilized pectinase. The immobilized protein in matrix was determined by subtracting unbound protein in the supernatant from the total protein used for immobilization.

\subsection{Evaluation of the hydrolytic properties of the co- polymer bound pectinase}

The hydrolytic properties of the copolymer bound pectinase as a hydrolase for polygalacturonic acid (PGA) were studied with respect to the reaction parameters such as temperature, $\mathrm{pH}$ and metal ions and compared with those of the free enzyme.

\subsubsection{Effect of temperature}

The effect of the reaction temperature on the activity of the free and immobilized pectinase for the hydrolysis of PGA was studied at $\mathrm{pH} 5.0$ in the temperature range $40-75^{\circ} \mathrm{C}$ under shaking (150 $\mathrm{rpm}$ ) for the maximal hydrolytic activity of the bound pectinase.

\subsubsection{Effect of the $\mathrm{pH}$}

The catalytic activity of the free and copolymer-bound pectinase in the hydrolysis of PGA at $60^{\circ} \mathrm{C}$ under shaking was investigated at different $\mathrm{pH}$ (4.5-6.5), and the residual pectinase activity was measured.

\subsubsection{Effect of salt ions}

The effect of ions on hydrolytic activity of the copolymer-bound pectinase was studied and compared to the initial pectinase activity, which was determined in the absence of salt ions. The copolymer bound pectinase was incubated for $1 \mathrm{~h}$ at room temperature in $10 \mathrm{mM}$ stock solutions of metal salts $\left(\mathrm{MgSO}_{4}, \mathrm{FeCl}_{3}\right.$, $\mathrm{HgCl}_{2}, \mathrm{CaCl}_{2}, \mathrm{MnCl}_{2}, \mathrm{ZnCl}_{2}, \mathrm{CuSO}_{4}, \mathrm{AlCl}_{3}, \mathrm{NaCl}$, and LiCO3). After $1 \mathrm{~h}$, the bound lipase was separated from the salt ions by centrifugation $(150 \mathrm{rpm})$ and was checked for pectinase activity at $60^{\circ} \mathrm{C}$.

\subsection{Stability of the copolymer-bound pectinase}

The copolymer bound pectinase was incubated at $60^{\circ} \mathrm{C}$ in a water bath under shaking. Its activity was checked against the hydrolysis of PGA in tri-sodium citrate buffer ( $\mathrm{pH}$ 5.0) after regular time intervals of $1 \mathrm{~h}$ and compared with the activity of free pectinase under the same conditions.

\subsection{Reusability of the copolymer-bound pectinase}

The reusability of the immobilized pectinase at $60^{\circ} \mathrm{C}, \mathrm{pH} 5.0$ was checked for 5 cycles. The enzyme activity after each cycle was measured.

\subsection{Characterization}

The Chitosan-co-PVA copolymer and the immobilized copolymer have been characterized by fourier Transform Infrared Spectroscopy, (FTIR), Scanning Electron Microscopy (SEM) and X-Ray Diffraction (XRD) techniques. The surface topology and homogeneity of the gelatin-co-PVA copolymer was studied by SEM QUANTA 250.

\section{Results and discussion}

\subsection{Synthesis of chitosan-co-PVA copolymer}

Ammonium persulfate, a well-known radical initiator, is used for polymerization and copolymerization reactions. Both sulfate radical ion and hydroxyl radicals from APS generate active sites on the polymer backbones through abstraction process. The active free radical sites on the polymer backbones offers sites for further reactions. In the present case, active radical sites, generated on the Chitosan and PVA polymer backbones, combine to yield the Chitosan-PVA copolymer, (Chs-co-PVA). Sodium bicarbonate is used, along with APS, as a foaming agent and helps to give a copolymer with good porosity.

The reaction parameters were optimized with respect to the swelling percentage studied as a function of time.

\subsubsection{Effect of $\mathrm{NaHCO3}$ concentration}

Fig.1 demonstrates the effect of $\mathrm{NaHCO}_{3}$ concentration on percent swelling of (Chs-co-PVA) copolymer. It is observed from the figure that percent swelling increases with increasing $\left[\mathrm{NaHCO}_{3}\right]$ and time of swelling giving maximum percentage swelling $(183.89 \%$ in $540 \mathrm{~min})$ at $13.88 \times 10^{-2} \mathrm{~mol} / \mathrm{L}$ of $\mathrm{NaHCO}_{3}$ beyond which it becomes constant. 


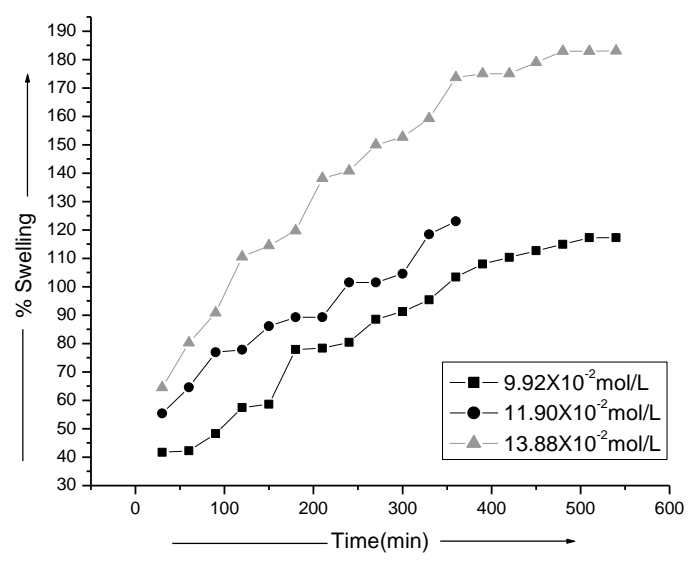

Fig. 1: Effect of $\left[\mathrm{Nahco}_{3}\right]$ on Percent Swelling of (Chs-Co-PVA) Copolymer.

\subsubsection{Effect of the APS concentration}

The relationship between the initiator concentration and water absorbency characteristics of (Chs-co-PVA) was studied as a function of APS concentration and the results are presented in Fig.2. Percent swelling increases with increasing [APS], reaches maximum $(730.18 \%$ in $510 \mathrm{~min})$ at $[\mathrm{APS}]=22.00 \times 10^{-2} \mathrm{~mol} / \mathrm{L}$ and becomes constant thereafter.

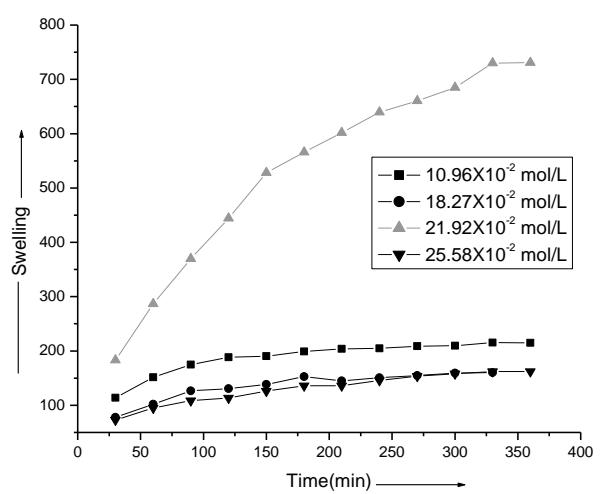

Fig. 2: Effect of [APS] on Percent Swelling of (Chs-Co-PVA) Copolymer.

\subsubsection{Effect of the amount of water}

The amount of water ascertains the formation of the copolymer which can holds its physical structure, obtained as a monolith, strongly. Therefore, the effect of water as a reaction medium on the swelling percentage of the copolymer was studied and the results are presented in Fig.3. It is observed from the figure that maximum percentage of swelling $(730.18 \%$ in $510 \mathrm{~min})$ was obtained for the sample prepared by using $3.0 \mathrm{~mL}$ of water. An increase or decrease in the amount of water beyond the optimum led to a decrease in the swelling percentage. The low swelling below 3 $\mathrm{mL}$ of water may be due to the insufficient amount of water for the homogenization of the reaction while the amounts higher than the optimum were found to be excessive for holding the copolymer structure.

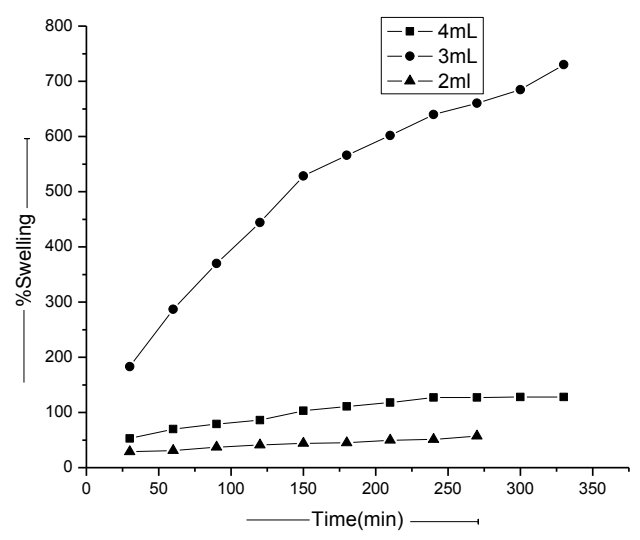

Fig. 3: Effect of Amount of Water on Percent Swelling of (Chs-Co-PVA) Copolymer.

\subsubsection{Effect of the temperature}

The effect of temperature on percent swelling of the copolymer, prepared in the temperature range $\left(50^{\circ} \mathrm{C}-75^{\circ} \mathrm{C}\right)$, was studied and the results are presented in Fig.4. Percent swelling increases with increasing temperature and time of swelling, giving maximum swelling $(730.18 \%$ in $510 \mathrm{~min})$ at $75^{\circ} \mathrm{C}$. At temperature lower than that of $75^{\circ} \mathrm{C}$, the initiator is not completely dissociated thus affecting the number of active sites on the polymers while at higher temperatures, increase in the chain transfer reactions results in the reduction of active sites on both Chitosan and PVA and hence the formation of the copolymer in both the cases is disturbed and lowering of percentage of swelling is observed.

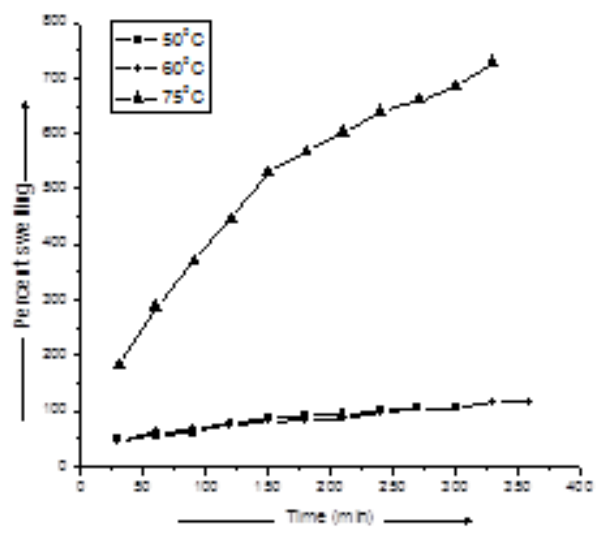

Fig. 4: Effect of Temperature on Percent Swelling of (Chs-Co-PVA) Copolymer.

\subsubsection{Effect of time}

Swelling percentage of (Chs-co-PVA) copolymers prepared at different reaction times was studied results are presented in Fig.5. It is observed from the figure that percent swelling increases with time of reaction and time of swelling giving maximum swelling (730.18\% in 510min) for the samples prepared for $4 \mathrm{~h}$ of reaction time beyond which it decreases. Low swelling in samples, prepared at reaction time less than $4 \mathrm{~h}$ is due to insufficient time for completely activating Chitosan and PVA backbones and hence the formation of the copolymer. However, increase in the time of reaction, beyond the optimum; affects the copolymer structures due to chain scission reactions affecting swelling characteristics of the copolymer. 


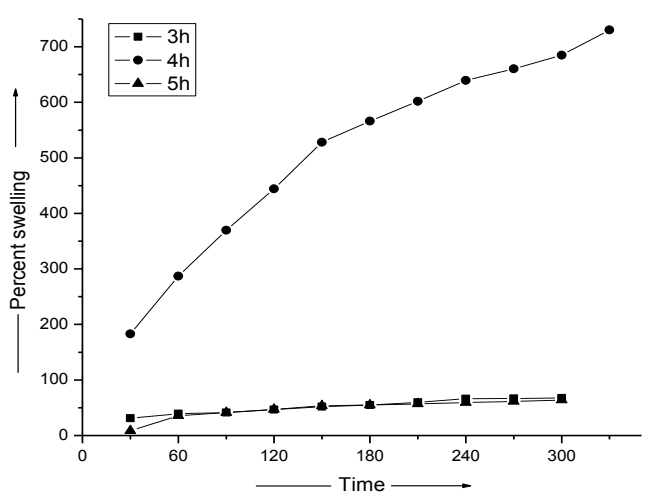

Fig. 5: Effect of Time on Percent Swelling of (Chs-Co-PVA) Copolymer.

\subsection{Characterization of the Chs-co-PVA copolymer}

\subsubsection{FTIR spectroscopy}

FTIR spectra of Chs-co-PVA copolymer and Chs-co-PVA copolymer immobilized pectinase enzyme are presented in Fig 6. The spectrum of the copolymer shows a broad band between 3600 $2800 \mathrm{~cm}^{-1}$ due to associated hydroxyl groups of Chitosan and PVA. The peak covering the region between 1650 and $1500 \mathrm{~cm}^{-1}$ is due to the carbonyl and N-H stretching of the acetylated groups of the Chitosan. In the IR spectrum of the enzyme immobilized Chs-co-PVA copolymer, the broad peak of the associated $\mathrm{O}-\mathrm{H}$ groups becomes moderately sharp between $3500-3400 \mathrm{~cm}^{-1}$ and a sharp peak at $1625 \mathrm{~cm}^{-1}$ due to $>\mathrm{C}=\mathrm{O}$ of carboxylic acid and a peak at $1100 \mathrm{~cm}^{-1}$ of ether linkage of the pectinase appear indicating a successful binding of the enzyme on the copolymer matrix.

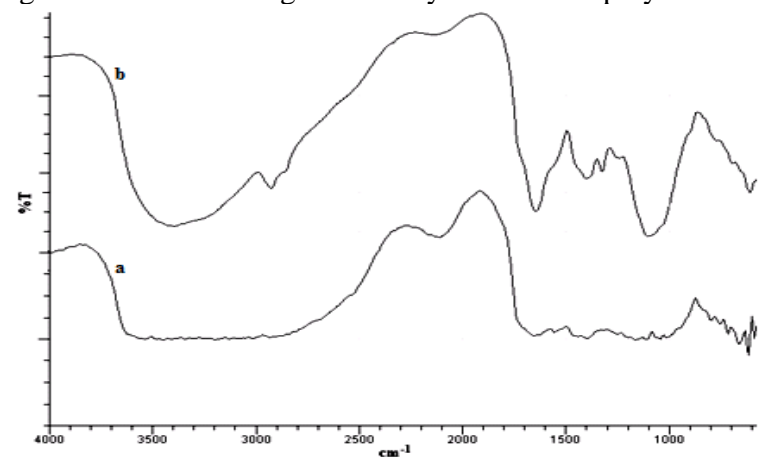

Fig. 6: IR Spectra of (A) (Chs-Co-PVA) and (B) Pectinase Immobilized (Chs-Co-PVA) Copolymer.

\subsubsection{Scanning electron microscopy}

Figure 7a \& b represents the SEM of the Chitosan and Chs-coPVA copolymer. It is observed from the figure that Chitosan has a smooth surface with straps and shrinkage which upon interaction with PVA yields (Chs-co-PVA) copolymer, that undergoes a change in the surface morphology exhibiting a thick dense but porous structure with small cavities distributed on the entire surface of copolymeric matrix.

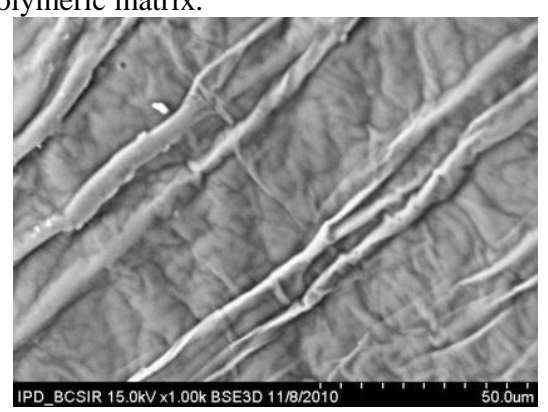

(a)

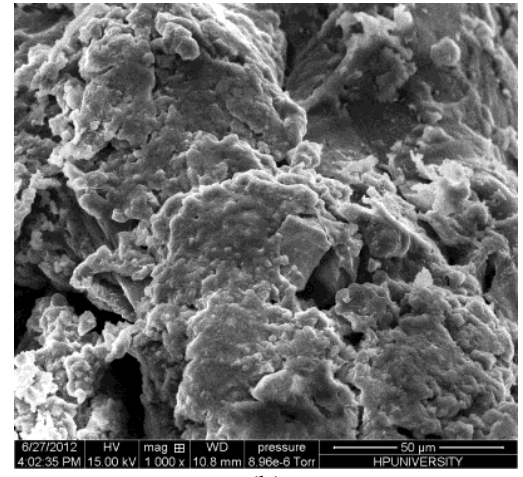

(b)

Fig. 7: SEM of (A) Chitosan (B) (Chs-Co-Pva) Copolymer.

\subsubsection{XRD}

X-ray diffraction studies of (Chs-co-PVA) was carried out and compared to that of pristine Chitosan and the respective diffractograms are presented in Figs. 8a \& b. XRD pattern of Chitosan (Fig.8a) shows two strong peaks at $22^{\circ}$ and $28^{\circ}$ on the $2 \Theta$ scale with respective intensities at 250 and 175 indicating amorphous nature of the polymer while the XRD patterns of the copolymer (Chs-co-PVA) shows a single peak at $22^{\circ}$ with increased intensity at 275 indicating that the copolymer attains crystalline nature upon reacting with PVA.

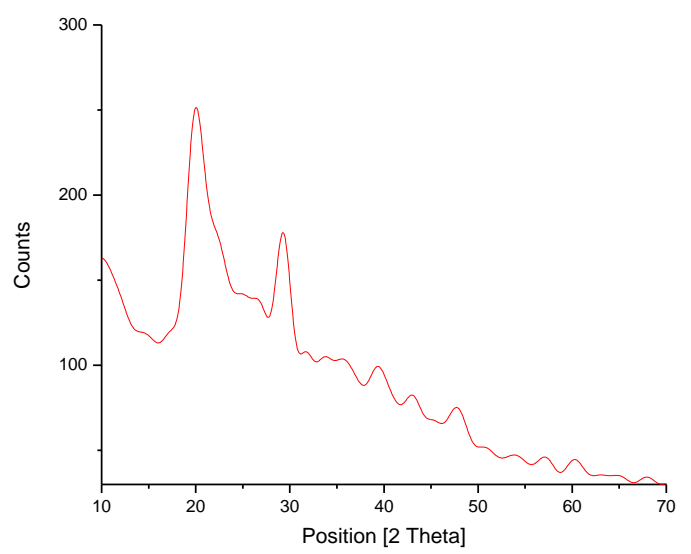

(a)

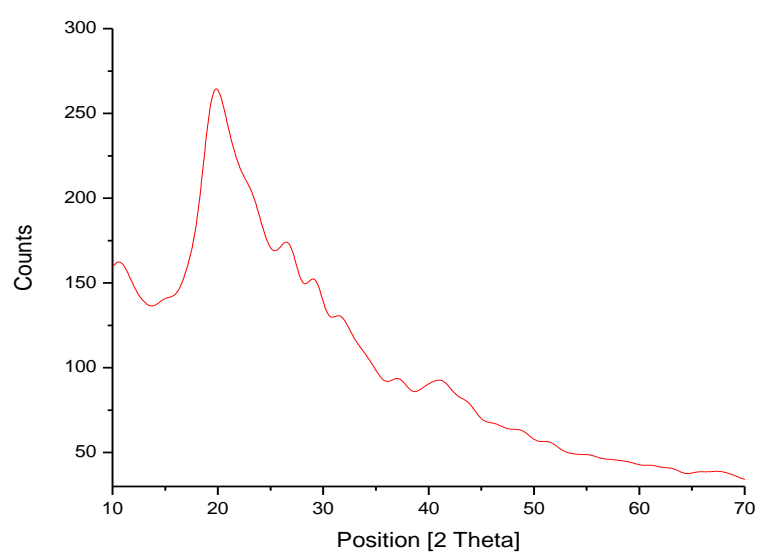

(b)

Fig. 8: XRD of (A) Pure Chitosan and (B) Chitosan-Co-PVA

\subsection{Immobilization of pectinase onto Chs-co-PVA Co- polymer}

The mode of binding of the protein and the ability of the support to retain the enzyme in its active form are important characteristics for the enzyme's utility. In the present study, the immobilization 
of pectinase onto the copolymer is through physical adsorption from its suspension in tri-sodium citrate buffer $(0.05 \mathrm{M}, \mathrm{pH} 5.0$, $15.98 \mathrm{U} / \mathrm{mL}$ activities). Maximum (72.28\%) protein binding efficiency at $\mathrm{pH} 5.0$ was observed. The enzyme binding efficiency was $88.29 \%$ and enzyme unbound efficiency was found to be $11.71 \%$

\subsection{Evaluation of the hydrolytic properties of the co- polymer bound pectinase}

The hydrolysis of PGA both by free pectinase and the copolymerbound pectinase was studied as a function of reaction variables such as the temperature and $\mathrm{pH}$, which affected the activity of the enzyme. The effect of different metal salts on the activity of the bound enzyme and the stability and reusability of the bound pectinase was also studied.

\subsubsection{Effect of the temperature on copolymer-bound pectinase activity}

The effect of the temperature on the activity of the immobilized pectinase and free pectinase for the hydrolysis of PGA at pH 5.0 was studied and the results are presented in Fig.9. It is observed from the figure that the activity of both free and the bound enzyme increases with temperature, giving maximum activity (15.88 $\mathrm{U} / \mathrm{mL}$ ) at $60^{\circ} \mathrm{C}$ beyond which it decreases to as low as $6.54 \mathrm{U} / \mathrm{mL}$ at $75^{\circ} \mathrm{C}$ for the free pectinse. In case of the immobilized pectinase, the activity was found to increase continuously with increasing temperature, giving a maximum activity of $14.13 \mathrm{U} / \mathrm{mL}$ at $65^{\circ} \mathrm{C}$. Further increase in the temperature led to the decrease in the activity to $10.55 \mathrm{U} / \mathrm{mL}$ at $75^{\circ} \mathrm{C}$ which is much better than that of free pectinase activity at this temperature.

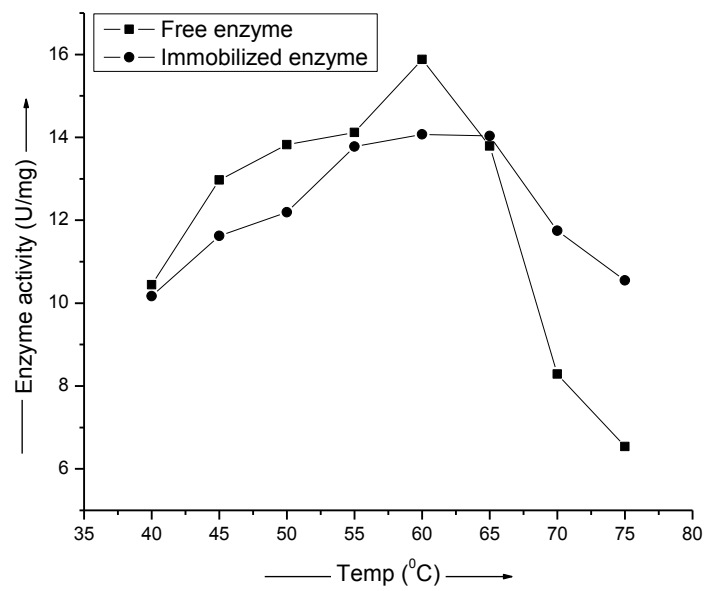

Fig. 9: Effect of Temperature on Free and Immobilized Pectinase Activity.

\subsubsection{Effect of the pH on the copolymer-bound pectinase ac- tivity}

The activity of the enzyme also depends on the $\mathrm{pH}$ of the medium in which the activity is to be measured. Therefore, in this study, the effect of the $\mathrm{pH}$ on the activity of the free pectinase and immobilized pectinase during the hydrolysis of PGA was studied, and the results are presented in Fig.10. The immobilized pectinase was found to be more stable and showed comparable maximum activity $(15.81 \mathrm{U} / \mathrm{mL})$ at higher $\mathrm{pH}(5.5)$ to the free pectinase which showed slightly higher activity $(15.95 \mathrm{U} / \mathrm{mL})$ at $\mathrm{pH} 5.0$. At $\mathrm{pH}$ higher than 5.5 also, the bound retains the activity better than the free enzyme. The $\mathrm{pH}$ effects could have manifested because of the partitioning of protons between the solution and the support surface thus affecting the reaction under study.

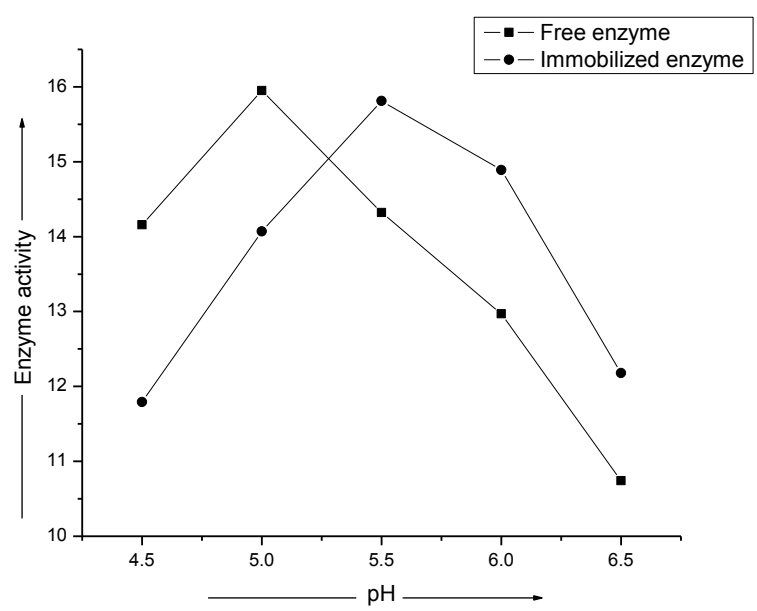

Fig. 10: Effect of pH on Free and Immobilized Pectinase Activity

\subsubsection{Effect of Salt ions on the copolymer-bound pectinase activity}

The effect of salt ions on the hydrolytic activity of pectinase incubated in salt ions $\left(10 \mathrm{mM}\right.$ stock solutions of $\mathrm{MgSO}_{4}, \mathrm{FeCl}_{3}, \mathrm{HgCl}_{2}$, $\mathrm{CaCl}_{2}, \mathrm{MnCl}_{2}, \mathrm{ZnCl}_{2}, \mathrm{CuSO}_{4}, \mathrm{AlCl}_{3}, \mathrm{NaCl}, \mathrm{LiCO}_{3}$ ) was determined and compared to the initial pectinase activity, which was determined in the absence of salt ions and the results are results in presented in Fig.11. All of the salts studied showed lower enzyme activity of pectinase as compared to the activity shown by the free pectinase and the bound enzyme. Among the various salts used, $\mathrm{CuSO}_{4}$ showed the highest activity $(13.63 \mathrm{U} / \mathrm{mg})$ which was found to be lower than the free enzyme $(15.98 \mathrm{U} / \mathrm{mL})$ and the bound enzyme $(15.81 \mathrm{U} / \mathrm{mg})$ while the activity in the presence of other metal salts lies between $6.57 \mathrm{U} / \mathrm{mg}$ to $12.95 \mathrm{U} / \mathrm{mg}$. The decrease in the activity may be due to the reason that the metal ions interacts with the active functionalities on the enzyme thus blocking the active sites involved in the hydrolysis and hence lower efficiency is observed.

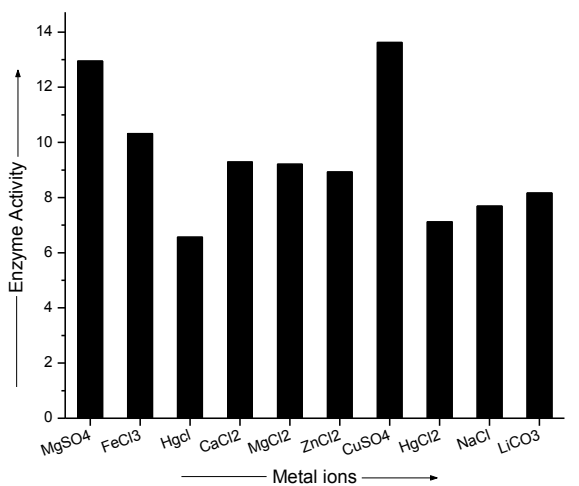

Fig. 11: Effect of Metal Ions on the Activity of Immobilized Pectinase Activity.

\subsection{Storage stability of the copolymer-bound pectinase}

The hydrolytic activities of the free pectinase and copolymerbound pectinase were measured and compared as a function of storage time of incubation, and the results are presented in Fig. 12. It is observed from the figure that the activity of free pectinase decreased with increasing time of incubation from the maximum $(15.98 \mathrm{U} / \mathrm{mL})$ to $(0.002 \mathrm{U} / \mathrm{mL})$ after 40 days of incubation i.e., the activity of free enzyme decreased drastically with increasing number of days to $0.01 \%$ of relative activity in 40 days. In case of the copolymer-bound pectinase with hydrolytic activity $(14.09 \mathrm{U} / \mathrm{mg})$ showed slight decrease in its hydrolytic activity after 5days of 
incubation $(13.58 \mathrm{U} / \mathrm{mg})$, which further decreased to as low as $3.68 \mathrm{U} / \mathrm{mg}$ but higher than that of free enzyme after 40 days of incubation. The immobilized pectinase showed $3.68 \%$ of relative activity even after 40 days. The drastic decrease in stability of free enzyme may be attributed to the fact that the exposure of the active site to room temperature for a long time affected the active sites of the enzyme and hence decreased the activity.

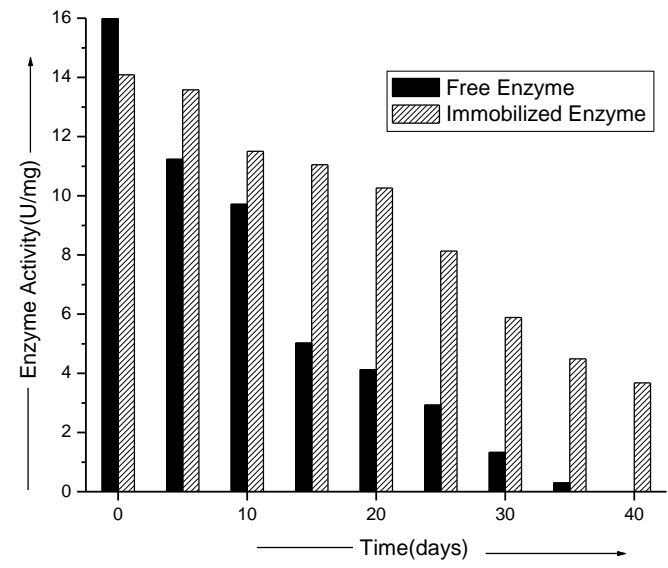

Fig. 12: Stability of Free and Immobilized Pectinase (Enzyme Activity).

\subsection{Reusability of the copolymer-bound pectinase}

The recycling capability of the immobilized pectinase was determined by reusing it to 5 cycles of hydrolysis of PGA and the results are presented in Fig. 13. The new substrate was added for new reaction until 5 batches and activity was measured after every cycle. It was observed that the activity of the immobilized pectinase started to decrease after first batch and $69.198 \%, 49.82 \%$ and $21.15 \%$ of the activity was shown after second, third and fourth batches. The activity decreased to $4.6 \%$ after the fifth cycle. This decrease might be due to the leaching out of the enzyme from the matrix due to repeated washings after every cycle or due to the conformational changes due to repeatedly using the enzyme (Rehman, 2014).

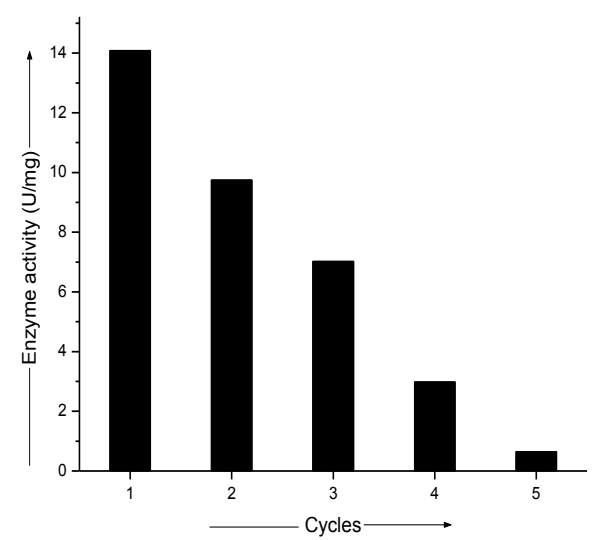

Fig. 13: Reusability of the Copolymer-Bound Pectinase

\section{Conclusion}

Chitosan and PVA are successfully copolymerized thermochemically and immobilization of the pectinase enzyme was achieved. The copolymer, Chs-co-PVA, showed good swelling properties and mechanical strength in comparison to pristine polymers, Chitosan and PVA. The hydrolytic activity of the bound enzyme towards the hydrolysis of PGA was successfully carried out and compared with that of the free enzyme. The bound en- zyme was more stable at different temperatures and $\mathrm{pH}$ values and also retained a higher hydrolytic activity.

\section{Acknowledgement}

One of the authors, Mr. Atul, is grateful to CSIR, New Delhi, for award of Junior Research Fellowship.

\section{References}

[1] Bajpai A and Manish S (2006) Preparation and Characterization of Novel pH-Sensitive Binary Grafted Polymeric Blends of Gelatin and Poly (vinyl alcohol): Water Sorption and Blood Compatibility Study. Journal of Applied Polymer Science 100, 599-617. http://dx.doi.org/10.1002/app.23370.

[2] Cascone MG, Barbani N, Cristallini C, Giusti P, Ciardelli G and Lazzeri L (2001) Bioartificial polymeric materials based on polysaccharides. Journal of Biomaterial Science Polymer Edition 12(3), 267.

[3] Coluccio ML, Ciardelli G, Berton F, Silvestri D, Cristallini C, Giusti P and Barbani N (2006) Enzymatic Erosion of Bioartificial Membranes to Control Drug Delivery. Macromolecular BioScience 6(6), 403-411. http://dx.doi.org/10.1002/mabi.200600022.

[4] Francois NJ, Allo S, Jacobo SE and Daraio ME (2007) Composites of polymeric gels and magnetic nanoparticles: preparation and drug release behavior. Journal of Applied Polymer Science 105, 647-55. http://dx.doi.org/10.1002/app.26321.

[5] Kumar K, Tripathi BP and Shahi VK (2009) Crosslinked chitosan/polyvinyl alcohol blend beads for removal and recovery of $\mathrm{Cd}$ (II) from wastewater. Journal of Hazardous Materials 172, 1041-1048. http://dx.doi.org/10.1016/j.jhazmat.2009.07.108.

[6] Lei CX, Hu SQ, Shen GL and Yu RQ (2003) Immobilization of horseradish peroxidase to a nano-Au monolayer modified chitosanentrapped carbon paste electrode for the detection of hydrogen peroxide. Talanta 59, 981-993. http://dx.doi.org/10.1016/S0039-9140 (02)00641-0.

[7] Lei Z and Bi S (2007) Preparation and properties of immobilized pectinase onto the amphiphilic PS-b-PAA diblock copolymers. Journal of Biotechnology 128, 112-119. http://dx.doi.org/10.1016/j.jbiotec.2006.09.002.

[8] Lei Z and Jiang Q (2011) Synthesis and properties of immobilized pectinase onto the macroporous polyacrylamide microspheres. Journal of Agricultural Food Chemistry 59(6), 2592-2599. http://dx.doi.org/10.1021/jf103719t.

[9] Liang S, Liu L, Huang Q and Yam KL (2009) Preparation of single or double-network chitosan/poly (vinyl alcohol) gel films through selectively cross-linking method. Carbohydrate Polymer 77, 718-724. http://dx.doi.org/10.1016/j.carbpol.2009.02.007.

[10]Lowry OH, Rosenbrough NJ, Farr AL and Randall R (1951) Protein measurement with the Folin phenol reagent. Journal of Biological Chemistry 193, 265.

[11]Majeti NV and Kumar R (2000) A review of chitin and chitosan. Reactive and Functional Polymer 46, 1. http://dx.doi.org/10.1016/S1381-5148 (00)00038-9.

[12] Nelson NA (1944) Photometric adaptation of the somogyi method for determination of glucose. Journal of Biological Chemistry 153, 375.

[13]Ngah W, Kamari WS and Koay AYJ (2004) Equilibrium and kinetics studies of adsorption of copper (II) on chitosan and chitosan/PVA beads. International Journal of Biological Macromolecules 34, 155161. http://dx.doi.org/10.1016/j.ijbiomac.2004.03.001

[14]Oh JK, Drumright R, Siegwart DJ and Matyjaszewski K (2008) the development of microgels/nanogels for drug delivery applications. Progress in Polymer Science 33, 448-477. http://dx.doi.org/10.1016/j.progpolymsci.2008.01.002.

[15]Prabaharan M and Mano JF (2005) Chitosan-based particles as controlled drug delivery systems. Drug Delivery 12, 41-57. http://dx.doi.org/10.1080/10717540590889781.

[16]Rehman HU, Aman A, Zohra RR and Qader SAU (2014) Immobilization of pectin degrading enzyme from Bacillus licheniformis KIBGE IB-21 using agar-agar as a support. Carbohydrate Polymers 102, 622626. http://dx.doi.org/10.1016/j.carbpol.2013.11.073.

[17]Roy I, Sardar M and Gupta, MN (2003) Evaluation of a smart bioconjugate of pectinase for chitin hydrolysis. Biochemical Engineering Journal 16 (3), 329-335. http://dx.doi.org/10.1016/S1369-703X (03)00112-8.

[18]Somogyi M (1952) Notes on sugar determination. Journal of Biological Chemistry 195, 19. 
[19]Szaniawski AR and Spencer HG (1997) Affects of immobilized pectinase on the microfiltratin of dilute pectin solutions by macroporous titania membranes: resistance model interpretation. Journal of Membrane Science 127, 69-76. http://dx.doi.org/10.1016/S0376-7388 (96)00299-2.

[20]Wang Q, Du YM and Fan LH (2005) Properties of chitosan/poly (vinyl alcohol) films for drug-controlled release. Journal of Applied Polymer Science 96, 808-813. http://dx.doi.org/10.1002/app.21518. 